\title{
FORMULASI PERMEN JELI SARI BUAH SINGI (Dillenia serrata Thunbr) KOMBINASI MADU MENGGUNAKAN GELATIN
}

\author{
${ }^{1}$ Nirwati Rusli, ${ }^{2}$ Putri Sabryna Ayu \\ 1,2 Program Studi DIII Farmasi, Politeknik Bina Husada Kendari, Sulawesi Tenggara, Indonesia \\ email:nirwatirusli@gmail.com
}

\begin{abstract}
ABSTRAK
Buah Singi adalah buah yang mengandung senyawa asam sitrat vitamin $\mathrm{C}$ dan beta karoten yang dapat memiliki efek bagi kesehatan tubuh. Madu berkhasiat menghasilkan energi, meningkatkan daya tahan tubuh dan meningkatkan stamina. Gelatin sebagai gelling agent dapat menghasilkan permen yang kenyal. Penelitian ini bertujuan untuk membuat sediaan permen jeli sari buah singi kombinasi madu menggunakan gelatin dan memilih konsentrasi gelatin yang paling optimum serta melihat apakah permen ini layak untuk dikonsumsi. Penelitian dilakukan secara eksperimen, sampel disari kemudian dibuat menjadi 3 formula dengan variasi konsentrasi gelatin 9\%, 10\%, dan 11\%. Hasil penelitian menunjukkan bahwa permen yang dibuat berwarna jingga kecoklatan, berbau khas dengan rasa asam manis dan teksturnya kenyal. Sediaan permen jeli dengan konsentrasi gelatin yang paling optimum adalah permen dengan konsentrasi gelatin 10\%. Hasil uji mikrobiologi menunjukkan bahwa permen jeli memenuhi syarat angka lempeng total, yaitu $3 \times 10^{3}$ dan angka kapang khamir $1 \times 10^{2}$ memenuhi syarat SNI pangan, yaitu angka lempeng total sebesar $3 \times 10^{3}$ dan angka kapang khamir sebesar $1 \times 10^{2}$.
\end{abstract}

Kata Kunci: Permen, gelatin, madu, buah singi.

\begin{abstract}
Singi fruit is a fruit that contains citric acid compound vitamin $C$ and beta carotene which can have an effect for health. Honey nutritious produce energy, increase endurance and stamina. Gelatin as gelling agent can produce the chewy candy. This research aims to make preparations jelly candy fruit juice Singi honey combination using gelatin and gelatin choose the most optimum concentration and see if candy is unfit for consumption Research conducted experiment, the sample series then made into 3 formulas with gelatin concentration variation $9 \%, 10 \%$ and $11 \%$. The results showed that the candy is made of orange-brown, distinctive smell, with a sweet and sour taste and chewy texture. Preparations candy jelly with gelatin optimum concentration is candy with a concentration of $10 \%$ gelatin. Microbiological test results showed that the jelly candy qualify total plate count is $3 \times 10^{3}$ and figures fungus yeast $1 \times 10^{2}$ qualified food SNI namely total plate count $3 \times 10^{3}$ and figures fungus yeast $1 \times 10^{2}$.
\end{abstract}

Keywords: Candy, gelatin, honey, singi fruit.

\section{PENDAHULUAN}

Sulawesi Tenggara terkenal dengan potensi sumber daya alam yang dimiliki termasuk buah-buahan tropis. Peluang pasar pengembangan komoditas buah-buahan, baik di tingkat regional dan nasional terus meningkat seiring dengan peningkatan konsumsi buah ditiap tahunnya, baik dalam bentuk segar maupun olahan.

Singi merupakan salah satu buah lokal dari Sulawesi Tenggara. Singi tersebar luas di Kabupaten Konawe. Tumbuhan singi tumbuh liar di hutan dan pekarangan masyarakat. Kekhasan yang dimiliki oleh buah singi ini 
terutama adalah pada rasa asam yang menyegarkan dan warna buah yang menarik. Selain penampilannya yang eksotik, buah singi mengandung vitamin $\mathrm{C}$ lebih dari $84 \%$ yang baik dikonsumsi untuk tubuh.

Permen merupakan salah satu bentuk makanan olahan dari pendidihan campuran gula dan sari buah (bahan pemberi rasa). Untuk mengolah buah-buahan menjadi permen lunak dilakukan dengan cara mendidihkan campuran gula, sari buah dan penambahan gelatin agar diperoleh tekstur yang kenyal dan penampilan yang jernih. Menurut penelitian Hasniarti (2012), perbandingan sari buah $40 \%$ dan gula $60 \%$ menghasilkan permen yang lebih disukai konsumen berdasarkan analisa kadar air, total asam dan gula reduksi serta uji organoleptik. Jumlah perbandingan gula yang tinggi dan sari buah yang rendah berpengaruh dalam penurunan kadar air dan berpengaruh terhadap peningkatan gula reduksi.

Gelatin adalah suatu produk yang diperoleh dari hidrolisis parsial kolagen yang berasal dari kulit, jaringan ikat dan tulang hewan. Gelatin dapat berfungsi sebagai pembentuk gel, pemantap emulsi, pengental, penjernih, pengikat air, pelapis dan pengemulsi. Dalam fungsinya sebagai pembentuk gel yaitu mengubah cairan menjadi padatan yang elastis, atau mengubah bentuk sol menjadi gel. Gelatin mempunyai sifat reversible yaitu jika gel dipanaskan akan membentuk sol dan bila didinginkan akan membentuk gel kembali. Keadaan ini yang membedakan gelatin dari bahan pengental lain seperti pektin, pati, low methoxy pektin, alginat, albumin telur dan protein susu yang bentuk gelnya irreversibel (Koswara, 2009).

Tujuan Penelitian adalah untuk membuat permen jeli sari buah singi kombinasi madu menggunakan gelatin dan untuk mengetahui konsentrasi gelatin yang digunakan dalam pembuatan permen jeli sari buah singi kombinasi madu, serta untuk mengetahui layak tidaknya permen jeli sari buah singi kombinasi madu menggunakan gelatin maka dilakukan uji mikrobiologi.

\section{METODE PENELITIAN}

\subsection{Alat}

Autoklaf, blender, cawan petri, cetakan permen, inkubator, lampu spiritus, ose bulat, oven, tabung reaksi, disposible syringe $1 \mathrm{~mL}$ dan $20 \mathrm{~mL}$.

\subsection{Bahan}

Akuades, buah singi, gelatin, kloramfenikol, madu, $\mathrm{NaCl}$, media Plate Count Agar (PCA), media Potato Dextrose Agar (PDA), tepung tapioka, Triphenyl Tetrazolium Chloride (TTC).

\subsection{Prosedur Kerja}

\subsubsection{Pembuatan Permen}

Dipanaskan sari buah singi, lalu ditambahkan gelatin, setelah semua tercampur dan mengental kemudian ditambahkan madu. Dimasukkan adonan jeli ke dalam wadah. 
Tabel 1. Formulasi Permen Jeli (tiap 7 gram)

\begin{tabular}{|c|c|c|c|c|c|}
\hline \multirow{2}{*}{ Komposisi } & \multicolumn{5}{|c|}{ Formula (\%) } \\
\hline & FA & & FB & & $\mathbf{C}$ \\
\hline Sari Buah Singi & 40 & & 40 & & 0 \\
\hline Madu & 30 & & 30 & & 0 \\
\hline Gelatin & 9 & & 10 & & 1 \\
\hline Tapioka & ad 100 & $\mathrm{ad}$ & 100 & $\mathrm{ad}$ & 100 \\
\hline
\end{tabular}

\subsubsection{Evaluasi Fisika Sediaan}

\section{Uji Organoleptik}

Karakteristik organoleptik diuji berdasarkan pada parameter organoleptik SNI permen jeli (SNI 3547.2-2008). Parameter organoleptik yang diuji meliputi rasa, bau, warna, dan tekstur (Badan Standarisasi Nasional, 2008)

\section{Uji Keseragaman Bobot}

Keseragaman bobot diukur dengan menimbang 20 permen secara satu per satu kemudian hitung bobot rata-rata permen.

\subsubsection{Uji Hedonik}

Uji mutu hedonik yang dilakukan terhadap permen jeli. Permen yang sudah diberi kode disajikan secara acak kepada 30 orang panelis, kemudian diminta untuk memberikan nilai menurut tingkat kesukaan (Wijana dkk, 2013).

\section{HASIL DAN PEMBAHASAN}

Tabel 2. Hasil Uji Organoleptik Permen Jeli Buah Singi Kombinasi Madu Menggunakan Gelatin

\begin{tabular}{llll}
\hline & \multicolumn{3}{c}{ Formula } \\
\cline { 2 - 4 } & \multicolumn{1}{c}{ FA } & \multicolumn{1}{c}{ FB } & \multicolumn{1}{c}{ FC } \\
\hline Warna & Jingga kecoklatan & Jingga kecoklatan & Jingga kecoklatan \\
Rasa & Asam manis & Asam manis & Asam manis \\
Aroma & Bau Khas & Bau Khas & Bau Khas \\
Tekstur & Kurang kenyal & Kenyal & Lebih Kenyal \\
\hline
\end{tabular}

\subsubsection{Uji Batas Cemaran Mikroba}

Penyiapan Sampel

Ditimbang sampel $\mathrm{F}_{\mathrm{A}}$ sebanyak 5 kantung sekitar 10 gram lalu dimasukkan ke erlenmeyer $250 \mathrm{~mL}$, tambahkan LB $90 \mathrm{~mL}$, lalu kocok hingga homogen dan diberi label pengenceran $10^{-1}$. Disiapkan 6 buah tabung reaksi dan pipet $9 \mathrm{~mL} \mathrm{NaCl}$ ke dalam tabung reaksi. Dipipet $1 \mathrm{~mL}$ suspensi pengenceran $10^{-1}$ ke dalam tabung reaksi yang berisi $9 \mathrm{~mL}$ $\mathrm{NaCl}$, dikocok homogen hingga diperoleh pengenceran $10^{-2}$. Dilakukan pengenceran bertingkat hingga diperoleh pengenceran $10^{-}$ 6. Dilakukan juga pengenceran pada $F_{B}, F_{C}$, $F_{D}$ dan $F_{E}$, kemudian hasil pengenceran selanjutnya dilakukan pengujian angka lempeng total (ALT) dan pengujian angka kapang khamir (AKK) (Utami, 2012). 
Tabel 3. Hasil Uji Keseragaman Bobot Permen Jeli Buah Singi Kombinasi Madu Menggunakan Gelatin

\begin{tabular}{cc}
\hline & Bobot Rata-rata \\
\hline Sebanyak 30 permen & 7.02 \\
\hline
\end{tabular}

Tabel 4. Hasil Uji HedonikPermen Jeli Buah Singi Kombinasi Madu Menggunakan Gelatin

\begin{tabular}{cccc}
\hline Parameter & \multicolumn{3}{c}{ Formula (\%) } \\
\cline { 2 - 4 } Uji & FA & FB & FC \\
\hline Sangat Suka & 16.67 & 76.67 & 23.53 \\
Cukup Suka & 60 & 23.33 & 33.33 \\
Tidak Suka & 23.33 & 0 & 43.33 \\
\hline
\end{tabular}

Tabel 5. Hasil Uji Angka Lempeng Total Permen Jeli Buah Singi Kombinasi Madu Menggunakan Gelatin

\begin{tabular}{|c|c|c|c|c|c|c|c|c|}
\hline \multirow{2}{*}{$\begin{array}{c}\text { Waktu } \\
\text { Inkubasi }\end{array}$} & \multicolumn{6}{|c|}{ Jumlah Koloni Tiap Cawan Petri } & \multirow{2}{*}{$\begin{array}{l}\text { Jumlah } \\
\text { Koloni }\end{array}$} & \multirow{2}{*}{$\begin{array}{l}\text { Batas Maksimum } \\
\text { Cemaran Mikroba }\end{array}$} \\
\hline & & $10^{-2}$ & $10^{-3}$ & $10^{-4}$ & $10^{-5}$ & $10^{-6}$ & & \\
\hline \multirow{2}{*}{72 jam } & 2 & 2 & 1 & 2 & 0 & 0 & \multirow{2}{*}{$3 \times 10^{4}$} & \multirow{2}{*}{$3 \times 10^{3} \mathrm{koloni} / \mathrm{g}$} \\
\hline & 1 & 1 & 2 & 2 & 0 & 0 & & \\
\hline
\end{tabular}

Tabel 6. Hasil Uji Angka Kapang Khamir Permen Jeli Buah Singi Kombinasi Madu Menggunakan Gelatin

\begin{tabular}{|c|c|c|c|c|c|c|c|c|}
\hline \multirow{2}{*}{$\begin{array}{c}\text { Waktu } \\
\text { Inkubasi }\end{array}$} & \multicolumn{6}{|c|}{ Jumlah Koloni Tiap Cawan Petri } & \multirow{2}{*}{$\begin{array}{l}\text { Jumlah } \\
\text { Koloni }\end{array}$} & \multirow{2}{*}{$\begin{array}{c}\text { Batas } \\
\text { Maksimum }\end{array}$} \\
\hline & & $10^{-2}$ & $10^{-3}$ & $10^{-4}$ & $10^{-5}$ & $10^{-6}$ & & \\
\hline \multirow{2}{*}{72 jam } & 1 & 1 & 1 & 0 & 0 & 0 & \multirow{2}{*}{$1 \times 10^{2}$} & \multirow{2}{*}{$1 \times 10^{2}$ koloni $/ g$} \\
\hline & 2 & 0 & 0 & 0 & 0 & 0 & & \\
\hline
\end{tabular}

\subsection{Uji Organoleptik}

Pada Tabel 2 menunjukkan bahwa permen dengan konsentrasi gelatin10\% adalah permen yang lebih baik dibandingkan dengan permen konsentrasi gelatin $9 \%$ dan $11 \%$ hal ini disebabkan karena permen dengan konsentrasi $10 \%$ memiliki tekstur yang sama dengan permen yang beredar dipasaran.

\subsection{Uji Keseragaman Bobot}

Keseragaman bobot merupakan syarat yang harus dipenuhi dalam produksi permen jeli. Sampel yang digunakan dalam pengujian ini diambil dari semua perlakuan yang diambil secara acak. Hasil pengamatan terhadap uji keseragaman bobot sediaan permen pada Tabel 3 menunjukkan bahwa sediaan permen yang dibuat mempunyai bobot yang seragam, yaitu 
dengan rata rata 7,02, dimana bobot rata - rata tersebut tidak menyimpang dari batas penyimpangan bobot.

\subsection{Uji Hedonik}

Uji kesukaan merupakan metode uji yang digunakan untuk mengukur tingkat kesukaan terhadap produk dengan menggunakan lembar penilain menurut standar SNI 01-2346-2006. Pada uji hedonik atau kesukaan dilakukan dengan memberikan kuisioner kepada 30 panelis untuk mengamati tampilan tekstur permen. Dari hasil uji hedonik secara umum panelis memilih formula B merupakan formula yang paling disukai dengan konsentrasi gelatin $10 \%$.

\subsection{Uji Angka Lempeng Total (ALT)}

Hasil perhitungan koloni bakteri melalui uji angka lempeng total pada sampel permen jeli yang dilakukan ternyata sampel menghasilkan jumlah koloni yang memenuhi batas cemaran bakteri pada sediaan permen jeli. Berdasarkan standar SNI, suatu permen jeli buah mempunyai batas maksimum ALT sebesar $3 \times 10^{3}$ koloni $/ g$ (Pratiwi, 2008), dari hasil tersebut menunjukkan bahwa sediaan tidak berbahaya dikonsumsi (Tabel 5).

\subsection{Uji Angka Kapang/Khamir}

$\begin{array}{crr}\text { Hasil } & \text { perhitungan } & \text { koloni } \\ \text { kapang/khamir, } & \text { ternyata } & \text { sampel }\end{array}$ menghasilkan jumlah koloni yang memenuhi batas cemaran kapang/khamir pada sediaan permen jeli. Berdasarkan SNI, suatu permen jeli buah dikatakan aman apabila total cemaran kapang/khamir 1 x $10^{2}$ koloni/g, maka dari hasil tersebut menunjukkan bahwa sediaan permen jeli ini tidak berbahaya dikonsumsi (Tabel 6).

\section{KESIMPULAN}

Gelatin dapat digunakan dalam pembuatan permen jeli sari buah singi kombinasi madu dan konsentrasi gelatin yang paling optimal sebagai pembentuk gel dalam pembuatan permen jeli adalah dengan konsentrasi $10 \%$, serta permen jeli sari buah singi layak dikonsumsi.

\section{UCAPAN TERIMA KASIH}

Ucapan terima kasih kepada Yayasan Bina Husada Kendari.

\section{DAFTAR PUSTAKA}

Badan Standarisasi Nasional (BSN). 2008. Kembang gula - Bagian 2: Lunak. SNI 3547.2-2008. Departemen Perindustrian.

Hasniarti. Studi Pembuatan Permen Buah Dengen (Dillenia Serrata Thunbr). Skripsi. Prodi Teknologi Pangan. Jurusan Teknologi Pertanian. Fakultas Pertanian UNHAS. Makassar. 2012

Koswara, S. 2009. Teknologi Pembuatan Permen. Diambil dari : http:/www.ebookpangan.com. Tgl. 3 Maret 2016.

Utami, Pinasti. 2012. Pengujian Mikrobiologi. (Diakses tanggal 18 April 2016)

http://bloggerjuniorindonesia.blogspot.co $\mathrm{m} / 2012 / 12$ pengujianmikrobiologi.html? $\mathrm{m}$ $=1$

Wijana, S dkk. 2013. Pembuatan Permen Jelly dari Buah Nanas (Ananas Comosus L.) Subgrade (Kajian Konsentrasi Karagenan dan Gelatin).Staff Pengajar Jurusan Teknologi Industri PertanianFakultas Teknologi Pertanian-Universitas Brawijaya Jl. Veteran-Malang 65145 